\title{
Mineralogical mosaics from the Carpathian-Pannonian region 4
}

\author{
ZAJZON, Norbert ${ }^{1 *}$, FeHÉR, Béla², SZAKÁLl Sándor ${ }^{1}$, KRISTÁLY, Ferenc $^{1}$ \\ ${ }^{1}$ Institute of Mineralogy and Geology, University of Miskolc, H-3515 Miskolc-Egyetemváros, Hungary \\ ${ }^{2}$ Department of Mineralogy, Herman Ottó Museum, Kossuth u. 13, H-3525 Miskolc, Hungary \\ *E-mail: nzajzon@uni-miskolc.hu \\ ORCID: 0000-0003-4664-8091
}

\section{Ásványtani mozaikok a Kárpát-Pannon régióból 4.}

Összefoglalás

Negyedik tanulmányunkban további mozaikszerú információkat közlünk a Kárpát-Pannon régió új ásványtani eredményeiből. Az adatokat országok és lelőhelyek szerint csoportosítottuk. Az egyes „mozaikdarabokban” az ásványok pontos leírására és - döntően XRPD, SEM-EDX és EMPA általi - meghatározására, illetve a paragenezis tömör bemutatására koncentráltunk. A tanulmányunkban szereplő ásványok olykor első említések az egész régióból vagy legalábbis az illető lelőhelyről.

Magyarországról a rudabányai ércesedésből freieslebenit és beaverit- $(\mathrm{Cu})$, a parádfürdői ércesedésből planeritaheylit-faustit-türkiz szilárd oldat vizsgálati adatait közöljük.

Romániából a rézbányai (Băița Bihor) ércesedésből konikalkit (magas Pb-tartalommal, konikalkit-duftit szilárd oldat) duftit és mottramit-duftit elegykristály, a vaskői (Ocna de Fier) ércesedésből pszeudomalachit álalak azurit után, illetve vauquelinit jelenlétét dokumentáltuk.

Szlovákiából a magloveci dioritprofirit kőfejtőből axinit-(Fe), a vehéci (Vechec) andezit-kőfejtőből bultfonteinit, míg a dobsinai (Dobšiná) polimetallikus ércesedésből botallackit jelenlétét igazoltuk.

Tárgyszavak: freieslebenit, beaverit-(Cu), planerit, konikalkit, duftit, mottramit, pszeudomalachit, vauquelinit, axinit-(Fe), bultfonteinit, botallackit

Abstract

This is the fourth paper presenting new mosaic-like mineralogical data from the Carpathian-Pannonian region. Data are arranged by countries and localities. Every section gives a description (including XRPD, EMPA and SEM-EDX results) of the minerals and a concise description of their parageneses. Every discussed mineral is first described from the given locality and in many instances even from the whole region.

From Hungary the following minerals are reported: freieslebenite and beaverite- $(\mathrm{Cu})$ from the Rudabánya ore deposit; and planerite-aheylite-faustite-turquoise solid-solution members from the Parádfürdő ore deposit.

From Romania the following minerals are identified: conichalcite (with high $\mathrm{Pb}$ content, conichalcite-duftite solid solution), duftite and mottramite-duftite solid-solutions from the Băița Bihor ore deposit, and pseudomalachite pseudomorph after azurite, as well as vauquelinite from the Ocna de Fier ore deposit.

From Slovakia the following minerals are described: axinite-(Fe) from the Maglovec diorite-porphyrite quarry, bultfonteinite from the Vechec andesite quarry and botallackite from the Dobšiná ore deposit.

Keywords: freieslebenite, beaverite- $(\mathrm{Cu})$, faustite, planerite, conichalcite, duftite, mottramite, pseudomalachite, vauquelinite, axinite$(\mathrm{Fe})$, bultfonteinite, botallackite

\section{Experimental methods and samples}

X-ray powder diffraction (XRPD) data were recorded on a Bruker D8 Advance diffractometer using $\mathrm{CuK \alpha}$ radiation (40 kV and $40 \mathrm{~mA}$ ) with a $250 \mathrm{~mm}$ radius goniometer. This involved parallel-beam geometry obtained by Goebel-mirror 2 optics, a $0.25^{\circ}$ primary axial Soller with $0.6 \mathrm{~mm}$ divergence slit, and a $0.12^{\circ}$ detector side long-Soller. Samples weighing from 1 to $5 \mathrm{mg}$ were ground in agate mortar under acetone and the obtained powder was poured on low-background single-crystal silicon sample holders. All measurements were recorded in the $2-70^{\circ}(2 \theta)$ range with a $0.01^{\circ}(2 \theta) / 2 \mathrm{sec}$ scanning rate. Identification of components was performedafter smoothing and background removal - by Search/ 
Match in Bruker DiffracPlus EVA 11.0.0.3. on a PDF-2 (2005) database. Intensities were extracted from the original scan after enhanced polynomial background subtraction.

Some XRPD measurements were carried out with a 114.6 mm-diameter Gandolfi camera (UB/61, Officina Elettrotecnica di Tenno, Trento, Italy) with Kodak Industrex MX 125 film; connected to a Siemens Kristalloflex 710 X-ray

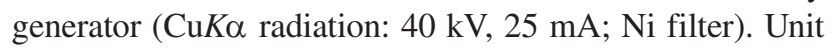
cell parameters were calculated with UnitCell software (HOLLAND \& REDFERN 1997). Film shrinkage was corrected by using a NIST SRM 640 silicon standard.

Scanning electron microscopy (SEM) studies, energydispersive X-ray spectroscopy (EDX), and X-ray mapping and electron microprobe measurements (EMPA) were performed using a JEOL JXA-8600 Superprobe unit. The microprobe was equipped with four wavelength-dispersive spectrometers and an EDX silicon drift detector (SDD). For the EDX measurements $15-20 \mathrm{kV}$ accelerating voltage was used, with a probe current of 10-20 nA. A $4 \times 5 \mu$ m area was scanned with focused beam during the analyses (a stopped focused beam was used if the target area was too small). These examinations were carried out at the Institute of Mineralogy and Geology, University of Miskolc.

Quantitative electron microprobe analyses were performed at the Geological Institute of Dionýz Štúr, Bratislava, Slovakia. A Cameca SX-100 instrument was used in wavelength-dispersive mode. The operating conditions were as follows: accelerating voltage: $15 \mathrm{kV}$; probe current: $20 \mathrm{nA}$; and beam diameters: $1-5 \mu \mathrm{m}$. The analytical standards were apatite (P), GaAs (As), stibnite (Sb), orthoclase $(\mathrm{Si}, \mathrm{K}), \mathrm{TiO}_{2}(\mathrm{Ti}), \mathrm{Al}_{2} \mathrm{O}_{3}(\mathrm{Al})$, fayalite $(\mathrm{Fe})$, forsterite $(\mathrm{Mg})$, wollastonite $(\mathrm{Ca})$, pure $\mathrm{Cu}(\mathrm{Cu})$, willemite $(\mathrm{Zn}), \mathrm{PbCO}_{3}$ $(\mathrm{Pb})$, and $\mathrm{LiF}(\mathrm{F})$. Raw intensity data were corrected using a PAP matrix correction (PouchOU \& PICHOIR 1984).

All the investigated samples are deposited in the mineral collection of the Herman Ottó Museum, Miskolc, Hungary.

\section{Results}

\section{HUNGARY}

\section{Freieslebenite from Rudabánya}

Numerous $\mathrm{Pb}-\mathrm{Sb}$ sulphosalts are known from the brecciated $\mathrm{Pb}$-Zn-baryte ore bodies of the Rudabánya hydrothermal ore mineralization (SZAKÁLL et al. 2005). The number of known sulphosalts from the location was extended by discovery of freieslebenite $\left(\mathrm{AgPbSbS}_{3}\right.$, identified by EPMA) from the galena-pyrargyrite association of the Villanytetô part of the mine. The irregular-shaped aggregates of freieslebenite can reach $0.1-0.2 \mathrm{~mm}$ in size and are usually closely intergrown with galena (Figure 1). Based on the textural observations on the BSE images, galena was replaced by freieslebenite from $\mu \mathrm{m}$ to $0.2 \mathrm{~mm}$ in size. Pyrargyrite can also be found in its close association with them. WDX analytical data (Table I) are close to the theoretical composition, where only minor Te, As and Bi content were detected.

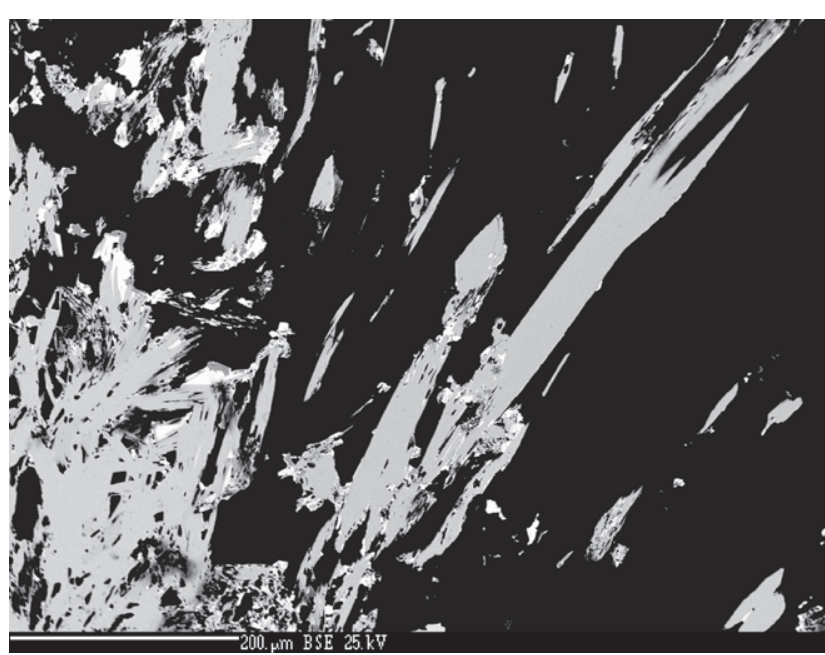

Figure 1. Fibrous aggregates of freieslebenite (grey) with minor galena (white) in carbonates (black). Villanytető mine, Rudabánya. BSE image

1. ábra. Freieslebenit szálas halmazai (szürke) kevés galenittel (fehér), karbonátokban (fekete). Rudabánya, Villanytetö bányarész. Visszaszórtelektron-kép

Table I. Electron microprobe data of freieslebenite from Rudabánya (in wt\%)

I. táblázat. A rudabányai freieslebenit elektron-mikroszondás elemzési adatai tömegszázalékban

\begin{tabular}{|l|r|r|r|r|}
\hline & 1 & 2 & 3 & $\begin{array}{r}\text { Average } \\
\text { Állag }\end{array}$ \\
\hline $\mathrm{Ag}$ & 18.90 & 20.45 & 20.34 & 19.90 \\
\hline $\mathrm{Pb}$ & 41.40 & 39.62 & 39.35 & 40.12 \\
\hline $\mathrm{Sb}$ & 21.38 & 22.48 & 22.68 & 22.18 \\
\hline $\mathrm{S}$ & 17.97 & 18.14 & 18.16 & 18.09 \\
\hline $\mathrm{Bi}$ & 0.06 & 0.10 & 0.06 & 0.07 \\
\hline $\mathrm{Te}$ & bdl. & bdl. & bdl. & 0.00 \\
\hline $\mathrm{As}$ & bdl. & bdl. & bdl. & 0.00 \\
\hline $\mathrm{Total}$ & 99.74 & 100.82 & 100.59 & 100.38 \\
$\mathrm{Összesen}$ & & & & \\
\hline \multicolumn{5}{|c|}{ lon numbers based on 3 sulphur atoms } \\
\hline $\mathrm{Ag}$ & 0.94 & 1.01 & 1.00 & 0.98 \\
\hline $\mathrm{Pb}$ & 1.07 & 1.01 & 1.01 & 1.03 \\
\hline $\mathrm{Sb}$ & 0.94 & 0.98 & 0.99 & 0.97 \\
\hline $\mathrm{S}$ & 3.00 & 3.00 & 3.00 & 3.00 \\
\hline $\mathrm{Bi}$ & 0.00 & 0.00 & 0.00 & 0.00 \\
\hline $\mathrm{Te}$ & 0.00 & 0.00 & 0.00 & 0.00 \\
\hline $\mathrm{As}$ & 0.00 & 0.00 & 0.00 & 0.00 \\
\hline
\end{tabular}

bdl. = below detection limit $/$ a detektálási határ alatt

As was corrected interference with $\mathrm{Pb} /$ As értéke korrigálva a $\mathrm{Pb}$ interferenciájval.

$\mathrm{Fe}, \mathrm{Se}, \mathrm{Cu}$ and $\mathrm{Cl}$ were below the detection limit / $\mathrm{Fe}$, Se, $\mathrm{Cu}$ és $\mathrm{Cl}$ a kimutatási határ alatt.

\section{Beaverite- $(\mathrm{Cu})$ from Rudabánya}

Smithsonite-bearing, fine-grained clayey material can be found in Triassic marl on the rims of the stratiform $\mathrm{Zn}-\mathrm{Pb}$ ore bodies as a result of alteration. The largest part of this alteration zone is at the border of the Andrássy I and Adolf mines. The following minerals were identified close to smithsonite: cerussite, anglesite, gypsum, baryte, musco- 


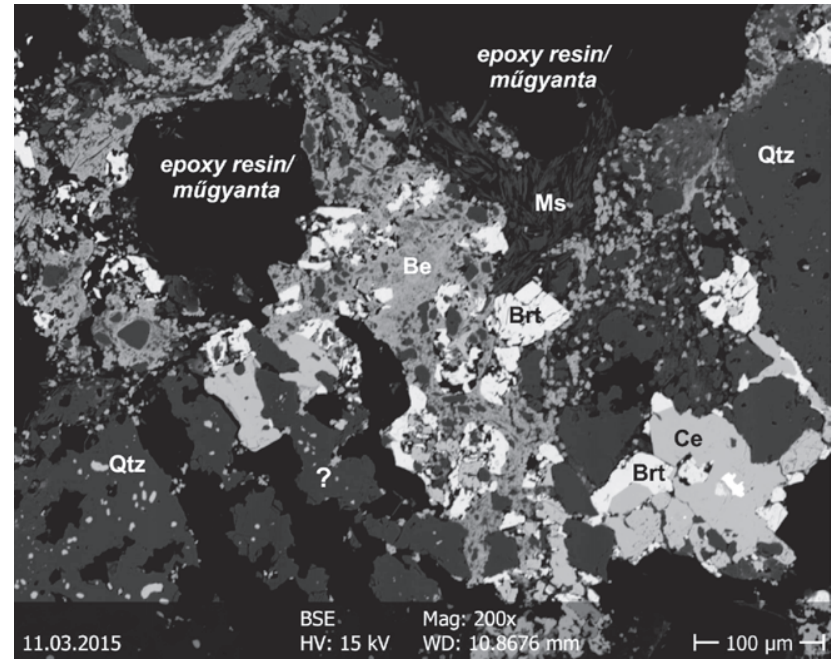

Figure 2. Chemically inhomogeneous (Fe-Al zonation) beaverite- $(\mathrm{Cu})$ aggregates $(\mathrm{Be})$ with baryte $(\mathrm{Brt})$ and cerussite $(\mathrm{Ce})$ in a muscovite $(\mathrm{Ms})$ and quartz (Qtz) matrix. Rudabánya, Adolf mine. BSE image

2. ábra. Beaverit-(Cu) kémiailag inhomogén (Fe-Al zónásság) halmazai (Be) barittal (Brt) és cerusszittal (Ce), muszkovit (Ms) és kvarc (Qtz) alapanyagban. Rudabánya, Adolf-bányarész. Visszaszórtelektron-kép

vite, and quartz. $\mathrm{Cu}$-containing sulphates like brochantite, linarite and rare beaverite- $(\mathrm{Cu})$ are also characteristic in some nests. The finely-dispersed beaverite- $(\mathrm{Cu})\left[\mathrm{Pb}_{0.5}\left(\mathrm{Cu}^{2+}\right.\right.$, $\left.\mathrm{Fe}^{3+}, \mathrm{Al}\right)_{3}\left(\mathrm{SO}_{4}\right)_{2}(\mathrm{OH})_{6}$ ] gives a pistachio-green colour to the clayey rock. This beaverite- $(\mathrm{Cu})$ is chemically inhomogeneous, where minor $\mathrm{Al}-\mathrm{Fe}$ zonation is visible in those forming patches according to the EPMA measurements and the BSE image (Figure 2). The presence of potassium and sili-

Table II. Electron microprobe data of beaverite$(\mathrm{Cu})$ in $\mathrm{wt} \%$

II. táblázat. Beaverit-(Cu) elektron-mikroszondás elemzési adatai tömegszázalékban

\begin{tabular}{|l|r|r|r}
\hline & 1 & 2 & 3 \\
\hline $\mathrm{SO}_{3}$ & 15.98 & 15.94 & 18.94 \\
\hline $\mathrm{P}_{2} \mathrm{O}_{5}$ & 2.33 & 2.08 & 0.91 \\
\hline $\mathrm{As}_{2} \mathrm{O}_{5}$ & 0.24 & 0.33 & 0.23 \\
\hline $\mathrm{SiO}_{2}$ & 7.98 & 7.83 & 7.22 \\
\hline $\mathrm{Al}_{2} \mathrm{O}_{3}$ & 9.09 & 8.32 & 4.26 \\
\hline $\mathrm{Fe}_{2} \mathrm{O}_{3}$ & 14.63 & 15.80 & 16.76 \\
\hline $\mathrm{CaO}$ & 0.17 & 0.14 & 0.09 \\
\hline $\mathrm{CuO}$ & 10.49 & 11.15 & 11.83 \\
\hline $\mathrm{ZnO}$ & 0.24 & 0.27 & 0.17 \\
\hline $\mathrm{Pb0}$ & 31.25 & 31.75 & 30.64 \\
\hline $\mathrm{Na}_{2} \mathrm{O}$ & 0.00 & 0.00 & 0.00 \\
\hline $\mathrm{K}_{2} \mathrm{O}$ & 1.31 & 1.36 & 0.77 \\
\hline $\mathrm{Total}$ & & & \\
Összesen & 93.71 & 94.97 & 91.81 \\
\hline
\end{tabular}

The analytical data are affected by the presence of the fine-grained muscovite, quartz and cerussite matrix. Az elemzési adatokat befolyásolta a finomszemcsés muszkovit, kvarc and cerusszit alapanyag. con in the analyses are due to muscovite and quartz impurities (Table II). Some phosphate and minor arsenate can substitute the sulphate anion in the structure of beaverite. Relics of the original sulphides (pyrite, sphalerite, and galena) are well visible in the BSE images. Based on texture and paragenesis, beaverite-( $\mathrm{Cu})$ was formed by supergene processes.

\section{Planerite-faustite-aheylite-turquoise solid solution from Parádfürdó}

The Etelka open-pit and the Orczy adit, among some other localities, contain phosphates in the cracks of silicified veins as typical secondary products of the low-sulphidation stage mineralization of Parádfürdő. Previous studies (KoCH 1966, SZAKÁLL et al. 2005) described wavellite and variscite from the area. Another pale greenish-yellow phosphate, forming 0.2 to $0.5 \mathrm{~mm}$ spherical aggregates and based on its XRPD data (SZAKÁLL et al. 2012), belongs to the turquoise family (Plate I/1). Along the rims of the chemicallyhomogeneous spheres, tiny jarosite crystals can be found and these are easily visible in the BSE images (Figure 3).

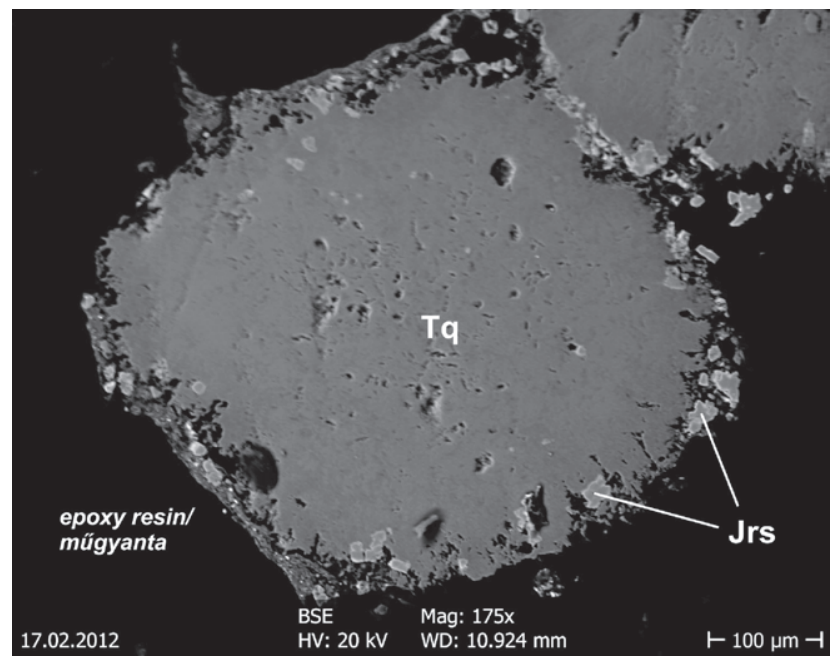

Figure 3. Spherical aggregate of a complex turquoise-group solid-solution member (Tq) with jarosite crystals (Jrs) along the rims. Egyesség adit, Parádfürdő. BSE image

3. ábra. A türkizcsoportba tartozó ásvány (Tq) gömbös aggregátuma a szegélyén jarositkristályokkal (Jrs). Parádfürdő, Egyesség-táró. Visszaszórtelektron-kép

The general formula of the turquoise-group minerals is $A_{0-1} B_{6}\left(\mathrm{PO}_{4}\right)_{4-\mathrm{x}}\left(\mathrm{PO}_{3} \mathrm{OH}\right)_{\mathrm{x}}(\mathrm{OH})_{8} \cdot 4 \mathrm{H}_{2} \mathrm{O}$, where numerous cations can enter in the divalent " $A$ " and trivalent " $B$ " sites. Based on earlier studies, the " $A$ " site is not always fully occupied. Thus, according to the redefinition of the group, the vacancy-dominant member is planerite (FOORD \& TAGGART 1998). Based on the WDX measurements obtained, in the phase at Parádfürdő, the " $A$ " site is almost exactly half vacant, whereas the other half contains $\mathrm{Zn}^{2+}, \mathrm{Fe}^{2+}$ and $\mathrm{Cu}^{2+}$ (Table III). Taking into account the half-vacant " $A$ " site and the only Al-containing " $B$ " site, the phase is a solid solution among planerite-aheylite-faustite-turquoise minerals (SZAKÁLl et al. 2012). The ideal formulae for the endmembers are: aheylite $\mathrm{Fe}^{2+} \mathrm{Al}_{6}\left(\mathrm{PO}_{4}\right)_{4}(\mathrm{OH})_{8} \bullet 4 \mathrm{H}_{2} \mathrm{O}$, faustite 
Table III. Electron-microprobe data of the turquoise-group minerals from Parádfürdő (in wt\%)

III. táblázat. A türkizcsoportba tartozó parádfürdői ásványok elektron-mikroszondás elemzési adatai tömegszázalékban

\begin{tabular}{|c|c|c|c|c|c|c|c|c|c|}
\hline & 1 & 2 & 3 & 4 & 5 & 6 & 7 & 8 & 9 \\
\hline $\mathrm{SO}_{3}$ & 0.21 & 0.21 & bdl. & bdl. & bdl. & bdl. & bdl. & bdl. & bdl. \\
\hline $\mathrm{P}_{2} \mathrm{O}_{5}$ & 36.45 & 37.04 & 35.89 & 36.02 & 36.48 & 36.69 & 36.25 & 36.53 & 36.00 \\
\hline $\mathrm{As}_{2} \mathrm{O}_{5}$ & 0.31 & 0.29 & bdl. & bdl. & bdl. & bdl. & bdl. & bdl. & bdl. \\
\hline $\mathrm{SiO}_{2}$ & 0.04 & 0.01 & bdl. & bdl. & bdl. & bdl. & bdl. & bdl. & bdl. \\
\hline $\mathrm{Al}_{2} \mathrm{O}_{3}$ & 39.24 & 42.25 & 39.23 & 38.26 & 37.49 & 37.98 & 39.04 & 38.32 & 39.26 \\
\hline $\mathrm{FeO}$ & 1.38 & 1.40 & 1.75 & 1.62 & 1.58 & 1.80 & 1.76 & 1.56 & 1.51 \\
\hline $\mathrm{CaO}$ & 0.08 & 0.10 & bdl. & bdl. & bdl. & bdl. & bdl. & bdl. & bdl. \\
\hline $\mathrm{CuO}$ & 0.90 & 0.94 & 1.29 & 1.34 & 1.14 & 1.19 & 1.13 & 0.79 & 1.14 \\
\hline $\mathrm{ZnO}$ & 3.53 & 3.59 & 2.38 & 2.23 & 2.36 & 2.09 & 2.28 & 2.03 & 2.00 \\
\hline $\mathrm{Pb0}$ & 0.04 & 0.03 & bdl. & bdl. & bdl. & bdl. & bdl. & bdl. & bdl. \\
\hline $\mathrm{Na}_{2} \mathrm{O}$ & 0.01 & 0.00 & bdl. & bdl. & bdl. & bdl. & bdl. & bdl. & bdl. \\
\hline $\mathrm{K}_{2} \mathrm{O}$ & 0.03 & 0.03 & bdl. & bdl. & bdl. & bdl. & bdl. & bdl. & bdl. \\
\hline Total & 82.22 & 85.89 & 80.54 & 79.47 & 79.05 & 79.75 & 80.46 & 79.23 & 79.91 \\
\hline \multicolumn{10}{|c|}{$\begin{array}{l}\text { Cation numbers based on } 20 \text { oxygen atoms } \\
\text { Kationszámok } 20 \text { oxigénatomra számolva }\end{array}$} \\
\hline$S$ & 0.02 & 0.02 & & & & & & & \\
\hline$P$ & 4.06 & 3.95 & 4.06 & 4.12 & 4.19 & 4.18 & 4.10 & 4.17 & 4.09 \\
\hline As & 0.02 & 0.02 & & & & & & & \\
\hline $\mathrm{Si}$ & 0.01 & 0.00 & & & & & & & \\
\hline$\Sigma T$ & 4.11 & 3.99 & 4.06 & 4.12 & 4.19 & 4.18 & 4.10 & 4.17 & 4.09 \\
\hline $\mathrm{Al}$ & 6.08 & 6.28 & 6.19 & 6.10 & 5.99 & 6.02 & 6.15 & 6.08 & 6.20 \\
\hline$\Sigma B$ & 6.08 & 6.28 & 6.19 & 6.10 & 5.99 & 6.02 & 6.15 & 6.08 & 6.20 \\
\hline $\mathrm{Fe}^{2+}$ & 0.15 & 0.15 & 0.20 & 0.18 & 0.18 & 0.20 & 0.20 & 0.18 & 0.17 \\
\hline $\mathrm{Ca}$ & 0.01 & 0.01 & & & & & & & \\
\hline $\mathrm{Cu}$ & 0.09 & 0.09 & 0.13 & 0.14 & 0.12 & 0.12 & 0.11 & 0.08 & 0.12 \\
\hline $\mathrm{Zn}$ & 0.34 & 0.33 & 0.24 & 0.22 & 0.24 & 0.21 & 0.22 & 0.20 & 0.20 \\
\hline [] & 0.41 & 0.42 & 0.43 & 0.46 & 0.46 & 0.47 & 0.47 & 0.54 & 0.51 \\
\hline$\Sigma A$ & 1.00 & 1.00 & 1.00 & 1.00 & 1.00 & 1.00 & 1.00 & 1.00 & 1.00 \\
\hline $\begin{array}{l}\text { Mineral } \\
\text { Ásvány }\end{array}$ & $\begin{array}{r}\text { faustite } \\
\text { faustit }\end{array}$ & $\begin{array}{r}\text { faustite } \\
\text { faustit }\end{array}$ & $\begin{array}{r}\text { faustite } \\
\text { faustit }\end{array}$ & $\begin{array}{r}\text { faustite } \\
\text { faustit }\end{array}$ & $\begin{array}{r}\text { faustite } \\
\text { faustit }\end{array}$ & $\begin{array}{r}\text { faustite } \\
\text { faustit }\end{array}$ & $\begin{array}{l}\text { faustite } \\
\text { faustit }\end{array}$ & $\begin{array}{l}\text { planerite } \\
\text { planerit }\end{array}$ & $\begin{array}{l}\text { planerite } \\
\text { planerit }\end{array}$ \\
\hline
\end{tabular}

bdl. = below detection limit $/$ a detektálási határ alatt.

$\mathrm{ZnAl}_{6}\left(\mathrm{PO}_{4}\right)_{4}(\mathrm{OH})_{8} \bullet 4 \mathrm{H}_{2} \mathrm{O}$, turquoise $\mathrm{CuAl}_{6}\left(\mathrm{PO}_{4}\right)_{4}(\mathrm{OH})_{8} \bullet$ $4 \mathrm{H}_{2} \mathrm{O}$ and planerite [] $\mathrm{Al}_{6}\left(\mathrm{PO}_{4}\right)_{2}\left(\mathrm{PO}_{3} \mathrm{OH}\right)_{2}(\mathrm{OH})_{8} \cdot 4 \mathrm{H}_{2} \mathrm{O}$. According to the dominant-valency rule of the IMA CNMNC (HATERT \& BURKE 2008), the turquoise-group mineral is planerite, if [] $>\Sigma R^{2+}$ in the " $A$ " site, otherwise (i.e. [] $<\Sigma R^{2+}$ ) the dominant divalent cation is the basis for classification. Therefore, some analyses of the material found at Parádfürdô correspond to the composition range of faustite $\left([]<\Sigma R^{2+}\right.$ ) with $\mathrm{Zn}$-dominance among the $R^{2+}$ cations (see Table III, columns 1-7); while others correspond to planerite ([]>0.5 apfu) - see Table III, columns 8-9.

The results of the XRPD measurement are shown in Table E1 (see the electronic supplementary materials). The observed reflections fit well with the literature data for planerite and faustite. The cation content of the phase at Parádfürdő reflects the dominant sulphides (chalcopyrite, tetrahedrite/tennantite, pyrite, and sphalerite) of the local ore mineralization. The " $A$ " site cations originate from the alteration of sulphides, whereas the $\mathrm{Al}$ and $\mathrm{P}$ are derived from the alteration of the rock-forming minerals. This is the first Carpathian occurrence of planerite.

\section{ROMANIA}

Conichalcite-duftite and mottramite-duftite solid solutions from Băița Bihor (Rézbánya)

The oxidation zone of the Băița Bihor ore deposit was very rich in different secondary copper minerals, and this zone is well-described in the study of STOICI (1983). Here previously unknown (for the location) arsenates are described, as well as a vanadate mineral found by WDX measurements in a sample set collected a few years ago from the Blidar contact. The exact coordinates of the samples have not been preserved. Macroscopically green to pistachiogreen crystalline crusts and spherical aggregates can be found in a strongly-oxidized, limonite-dominant specimen, which is crosscut by calcite veins. These crusts and aggregates are built up by tabular or bladed crystals $10-40 \mu \mathrm{m}$ in length, forming spectacular fan-shaped forms. According to the XRPD measurements, the dominant phase in the crusts is conichalcite [ideally $\left.\mathrm{CaCu}\left(\mathrm{AsO}_{4}\right)(\mathrm{OH})\right]$. The crystals are chemically inhomogeneous, where the lead content showing the greatest variation. This is clearly visible in the BSE images (Figure 4). Sometimes a high $\mathrm{Ca}$ content was 


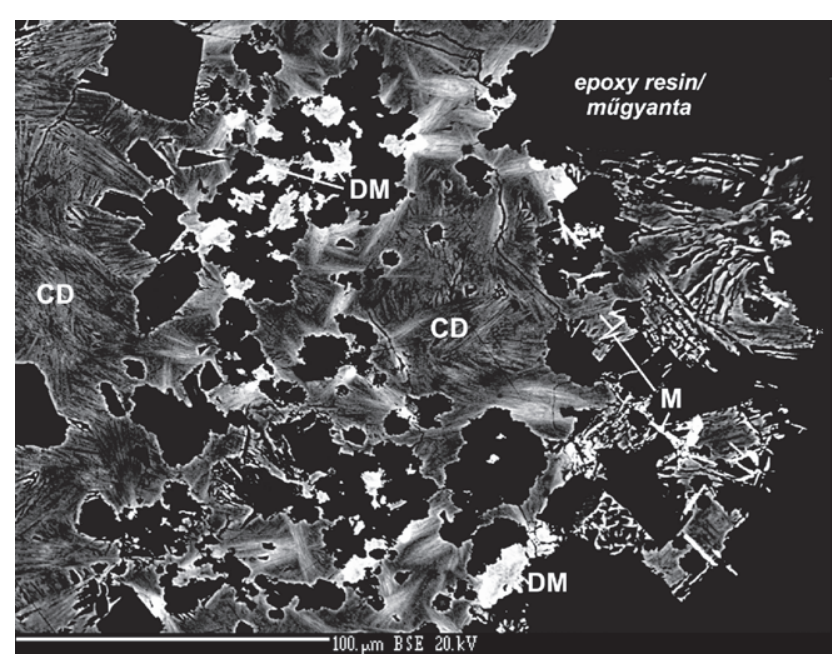

Figure 4. Chemically inhomogeneous conichalcite-duftite (CD: grey, fibrous aggregates) and duftite-mottramite aggregates (DM: white spots) with mimetite needles (M: white needles). Blidar complex, Băița Bihor. BSE image

4. ábra. Kémiailag inhomogén konikalkit-duftit (CD: szürke, rostos halmazok)és duftit-mottramit halmazok (DM: fehér foltok) tüs mimetezittel (M: fehér tük). Rézbánya, Blidár-komplexum. Visszaszórtelektron-kép

observed (Table IV), and this can be explained by a Ca-for$\mathrm{Pb}$ replacement. On the BSE image (Figure 4) 3-10 $\mu \mathrm{m}$ aggregates and sometimes dipyramids of mottramite-duftite can be observed in close association with duftite [ideally $\mathrm{PbCu}\left(\mathrm{AsO}_{4}\right)(\mathrm{OH})$ ] clusters. The chemistry of these phases scatters around the boundary between mottramite [ideally $\mathrm{PbCu}\left(\mathrm{VO}_{4}\right)(\mathrm{OH})$ ] and duftite as a result of the varying $\mathrm{As}-\mathrm{V}$ content, but mottramite is more characteristic for the studied sample. In rare instances 3-10 $\mu \mathrm{m}$-sized mimetite needles were also identified in this environment. The presence of the solid-solution series between mottramite and duftite is not surprising, since mottramite is the vanadium-dominant analogue of duftite with an isomorphous structure. An example of this was given by GuILLEMIN (1956) who mentioned mottramite-duftite solidsolution members from Tsumeb, Namibia. As suggested by the BSE images, at Băița Bihor mottramite-duftite and mimetite are the older precipitates, and these were followed by later-formed conichalcite-duftite.

\section{Pseudomalachite pseudomorphs after azurite, and vauquelinite from Ocna de Fier (Vaskó)}

Many interesting secondary minerals, e.g. well-formed crystals of veszelyite, were found in the forested waste dumps of the long-abandoned Reichenstein open-pit of the iron-ore deposit at Ocna de Fier (Banat region). The most interesting phase is pseudomalachite-pseudomorphing azurite. These secondary phases are located in the voids of the andradite-magnetite skarn formed by leaching and weathering of sulphides and carbonates. Based on XRPD measurement, the pale blue, $0.1 \mathrm{~mm}$-long, lath-shaped crystals (Plate 1/3) are still (albeit only partially) azurites and partially pseudomalachites (Table E2, see the electronic supplementary materials ). The well-visible zonation in the BSE images is caused by the varying phosphorus content (Figure 5). The accompanying minerals are globular malachite, rosasite, tabular veszelyite and transparent, lath-shaped hemimorphite. Similar pseudomalachite- pseudomorphs are also documented in other

Table IV. Electron microprobe data of conichalcite (1-4), duftite (5) and mottramite (6-8) from Băița Bihor (in wt \%)

IV. táblázat. A rézbányai konikalkit (1-4), duftit (5) és mottramit (6-8) elektron-mikroszondás elemzési adatai tömegszázalékban

\begin{tabular}{|c|c|c|c|c|c|c|c|c|}
\hline & 1 & 2 & 3 & 4 & 5 & 6 & 7 & 8 \\
\hline $\mathrm{SO}_{3}$ & 0.06 & 0.08 & 0.07 & 0.05 & 0.04 & 0.04 & 0.03 & 0.03 \\
\hline $\mathrm{V}_{2} \mathrm{O}_{5}$ & & & & & 9.70 & 10.52 & 11.54 & 11.18 \\
\hline $\mathrm{As}_{2} \mathrm{O}_{5}$ & 31.66 & 32.55 & 31.18 & 32.58 & 12.99 & 11.52 & 10.20 & 10.83 \\
\hline $\mathrm{SiO}_{2}$ & 0.98 & 0.77 & 0.98 & 0.99 & 0.56 & 0.64 & 0.73 & 0.68 \\
\hline $\mathrm{Fe}_{2} \mathrm{O}_{3}{ }^{*}$ & 0.01 & 0.04 & 0.00 & 0.01 & 0.18 & 0.19 & 0.18 & 0.18 \\
\hline $\mathrm{CaO}$ & 10.72 & 11.47 & 9.93 & 11.54 & 2.19 & 2.66 & 2.23 & 2.41 \\
\hline CuO & 24.70 & 25.08 & 24.45 & 25.23 & 20.61 & 20.80 & 20.75 & 20.76 \\
\hline $\mathrm{PbO}$ & 27.24 & 25.81 & 29.44 & 25.59 & 47.85 & 48.21 & 49.76 & 48.38 \\
\hline $\begin{array}{l}\text { Total } \\
\text { Összesen }\end{array}$ & 95.37 & 95.80 & 96.05 & 95.99 & 94.12 & 94.58 & 95.42 & 94.45 \\
\hline \multicolumn{9}{|c|}{$\begin{array}{l}\text { Cation numbers based on } 4.5 \text { oxygen atoms } \\
\text { Kationszámok } 4.5 \text { oxigénatomra számolva }\end{array}$} \\
\hline$S$ & 0.00 & 0.00 & 0.00 & 0.00 & 0.00 & 0.00 & 0.00 & 0.00 \\
\hline V & & & & & 0.44 & 0.48 & 0.52 & 0.51 \\
\hline As & 0.92 & 0.93 & 0.92 & 0.92 & 0.47 & 0.41 & 0.37 & 0.39 \\
\hline $\mathrm{Si}$ & 0.05 & 0.04 & 0.06 & 0.05 & 0.04 & 0.04 & 0.05 & 0.05 \\
\hline $\mathrm{Fe}$ & 0.00 & 0.00 & 0.00 & 0.00 & 0.01 & 0.01 & 0.01 & 0.01 \\
\hline $\mathrm{Ca}$ & 0.64 & 0.67 & 0.60 & 0.67 & 0.16 & 0.20 & 0.16 & 0.18 \\
\hline $\mathrm{Cu}$ & 1.04 & 1.03 & 1.04 & 1.03 & 1.07 & 1.08 & 1.08 & 1.08 \\
\hline $\mathrm{Pb}$ & 0.41 & 0.38 & 0.45 & 0.37 & 0.89 & 0.89 & 0.92 & 0.89 \\
\hline
\end{tabular}

* Total iron was calculated as $\mathrm{Fe}_{2} \mathrm{O}_{3} / \mathrm{Az}$ összes vas $\mathrm{Fe}_{2} \mathrm{O}_{3}$-ként számítva. 


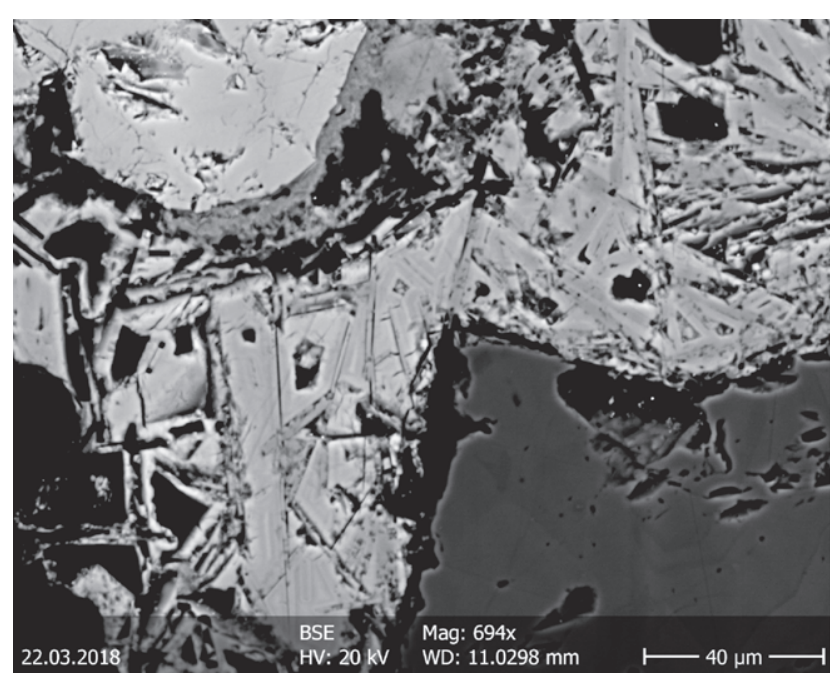

Figure 5. Chemical zonation in a pseudomalachite-pseudomorph after azurite aggregates with rosasite (grey) and andradite (dark grey). Reichenstein openpit, Ocna de Fier. BSE image

5. ábra. Kémiai zónásság pszeudomalachit azurit utáni pszeudomorfózáiban rosasittal (szürke) és andradittal (sötétszürke). Vaskö, Reichenstein-külfejtés. Visszaszórtelektron-kép

localities. For example, CRANE et al. (2001) mention pseudomalachite-pseudomorphs after azurite from site E27 near Northparkes (New South Wales, Australia). Here, azurite crystals encrusted by pseudomalachite were also observed.

Vauquelinite was also observed in the cavities of the andradite-magnetite skarn. Vauquelinite very occasionally occurs as brown dipyramids of up to $0.1 \mathrm{~mm}$ (Figure 6 ). The identification was made by XRPD measurement (Table E3, see the electronic supplementary materials). The elements $\mathrm{Pb}, \mathrm{Cu}, \mathrm{Cr}$ and $\mathrm{P}$ were detected by SEMEDX.

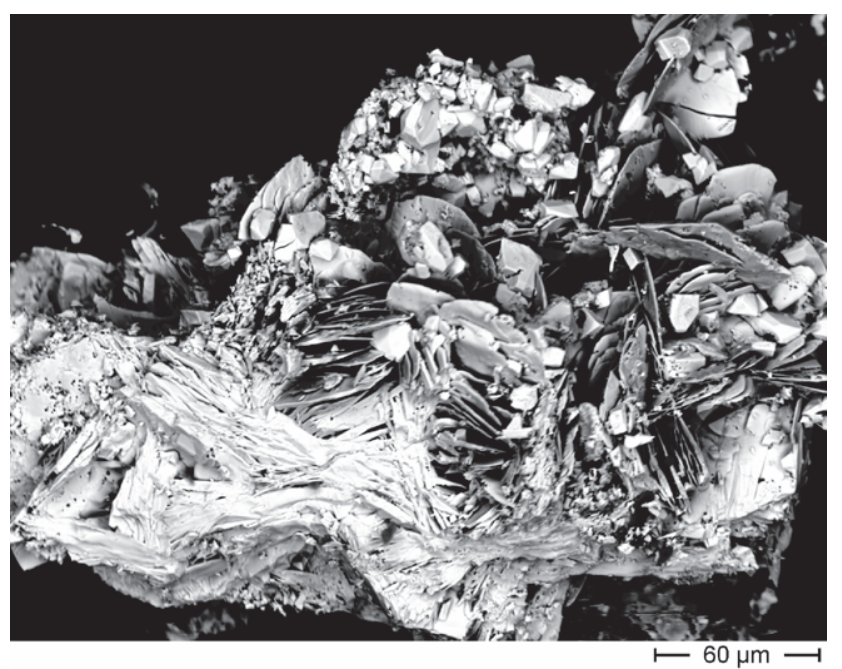

Figure 6. Vauquelinite crystals (bright) with tabular hydrozincite or smithsonite. Reichenstein open-pit, Ocna de Fier. BSE image

6. ábra. Vauquelinitkristályok(világos) táblás hidrocinkittel vagy smithsonittal. Vaskö, Reichenstein-külfejtés. Visszaszórtelektron-kép

\section{SLOVAKIA}

Axinite-( $\mathrm{Fe})$ from Maglovec quarry, Vyšná Šebastová (Felsősebes)

Based on chemical analyses, here a proper classification of axinite from Vyšná Šebastová is given according to recent nomenclature (SANERO \& GOTTARDI 1968). Axinite was first mentioned in the description of mineral assemblages from different xenoliths of the Maglovec diorite porphyry quarry

Table V. Electron microprobe data of axinite from Vyšná Šebastová (in wt\%)

V. táblázat. A felsősebesi axinit elektron-mikroszondás elemzési adatai tömegszázalékban

\begin{tabular}{|c|c|c|c|c|}
\hline & 1 & 2 & 3 & 4 \\
\hline $\mathrm{SiO}_{2}$ & 41.43 & 40.63 & 41.46 & 41.48 \\
\hline $\mathrm{TiO}_{2}$ & 0.09 & 0.12 & 0.13 & 0.10 \\
\hline $\mathrm{B}_{2} \mathrm{O}_{3}{ }^{*}$ & 6.05 & 6.06 & 6.10 & 6.07 \\
\hline $\mathrm{Al}_{2} \mathrm{O}_{3}$ & 17.17 & 18.49 & 16.36 & 17.46 \\
\hline $\mathrm{Fe}_{2} \mathrm{O}_{3}{ }^{* *}$ & 1.73 & 0.61 & 2.86 & 1.43 \\
\hline $\mathrm{MgO}$ & 0.58 & 0.53 & 0.32 & 0.57 \\
\hline $\mathrm{CaO}$ & 19.20 & 18.41 & 19.16 & 19.38 \\
\hline MnO & 4.38 & 4.81 & 4.81 & 5.19 \\
\hline $\mathrm{Fe} 0^{* *}$ & 7.82 & 8.59 & 7.52 & 6.80 \\
\hline $\mathrm{Na}_{2} \mathrm{O}$ & bdl. & 0.26 & 0.02 & bdl. \\
\hline $\mathrm{K}_{2} \mathrm{O}$ & bdl. & 0.01 & bdl. & bdl. \\
\hline $\mathrm{H}_{2} \mathrm{O}^{\star \star \star \star}$ & 1.57 & 1.57 & 1.57 & 1.57 \\
\hline Total & 100.03 & 100.08 & 100.30 & 100.05 \\
\hline \multicolumn{5}{|c|}{$\begin{array}{l}\text { Cation numbers based on } 16 \text { oxygen atoms } \\
\text { Kationszámok } 16 \text { oxigénatomra számolva }\end{array}$} \\
\hline $\mathrm{Si}$ & 3.95 & 3.87 & 3.96 & 3.94 \\
\hline $\mathrm{Al}$ & 0.05 & 0.13 & 0.04 & 0.06 \\
\hline$\Sigma T$ & 4.00 & 4.00 & 4.00 & 4.00 \\
\hline$B$ & 1.00 & 1.00 & 1.00 & 1.00 \\
\hline$\Sigma B$ & 1.00 & 1.00 & 1.00 & 1.00 \\
\hline $\mathrm{Al}$ & 1.88 & 1.95 & 1.80 & 1.90 \\
\hline $\mathrm{Fe}^{3+}$ & 0.12 & 0.05 & 0.20 & 0.10 \\
\hline$\Sigma Z$ & 2.00 & 2.00 & 2.00 & 2.00 \\
\hline $\mathrm{Ti}$ & 0.01 & 0.01 & 0.01 & 0.01 \\
\hline $\mathrm{Mg}$ & 0.08 & 0.07 & 0.05 & 0.08 \\
\hline $\mathrm{Mn}$ & 0.29 & 0.26 & 0.33 & 0.37 \\
\hline $\mathrm{Fe}^{2+}$ & 0.62 & 0.67 & 0.61 & 0.54 \\
\hline$\Sigma Y$ & 1.00 & 1.00 & 1.00 & 1.00 \\
\hline $\mathrm{Ca}$ & 1.96 & 1.88 & 1.96 & 1.97 \\
\hline $\mathrm{Mn}$ & 0.06 & 0.13 & 0.06 & 0.05 \\
\hline $\mathrm{Na}$ & 0.00 & 0.05 & 0.00 & 0.00 \\
\hline $\mathrm{K}$ & 0.00 & 0.00 & 0.00 & 0.00 \\
\hline$\Sigma X$ & 2.02 & 2.06 & 2.02 & 2.02 \\
\hline
\end{tabular}

* $\mathrm{B}_{2} \mathrm{O}_{3}$ calculated from the stoichiometry: $\mathrm{B}=1$ apfu $/ \mathrm{B}_{2} \mathrm{O}_{3} a$ sztöchiometrikus összetételböl számolva: $B=1$ apfu.

** $\mathrm{Fe}_{2} \mathrm{O}_{3} / \mathrm{FeO}$ was calculated from the equation ${ }^{\mathrm{Z}}\left(\mathrm{Al}+\mathrm{Fe}^{3+}\right)$ $=2.00$ apfu $/ \mathrm{A} \mathrm{Fe}_{2} \mathrm{O}_{3} / \mathrm{FeO}$ arány $\mathrm{a}^{\mathrm{z}}\left(\mathrm{Al}+\mathrm{Fe}^{3+}\right)=2.00$ apfu egyenletböl számolva.

$* * * \mathrm{H}_{2} \mathrm{O}$ calculated from the stoichiometry: $\mathrm{OH}=1 \mathrm{apfu} /$ $\mathrm{H}_{2} \mathrm{O}$ a sztöchiometrikus összetételböl számolva: $\mathrm{OH}=1$ apfu. bdl. below detection limit / a kimutatási határ alatt

$\mathrm{Cl}, \mathrm{Cr}$ and Ni were measured, but they were always below the detection limit / Cl, Cr és Ni mérve, de mindig a kimutatási határ alatt. 
nearby Vyšná Šebastová by ĎuĎA (1981). Bladed, purplish brown crystals $0.2-0.5 \mathrm{~mm}$ in size were investigated. Axinite forms sheaves grown on columnar danburite crystals in association with actinolite needles and yellow trapezohedral crystals of grossular. According to the WDX analyses (Table $V)$, axinite is a Mn-rich axinite-(Fe). Weak chemical zonation of $\mathrm{Fe}$ and $\mathrm{Mn}$ can be observed in the BSE images (Figure 7), where the brighter zones have a slightly higher Fe content.

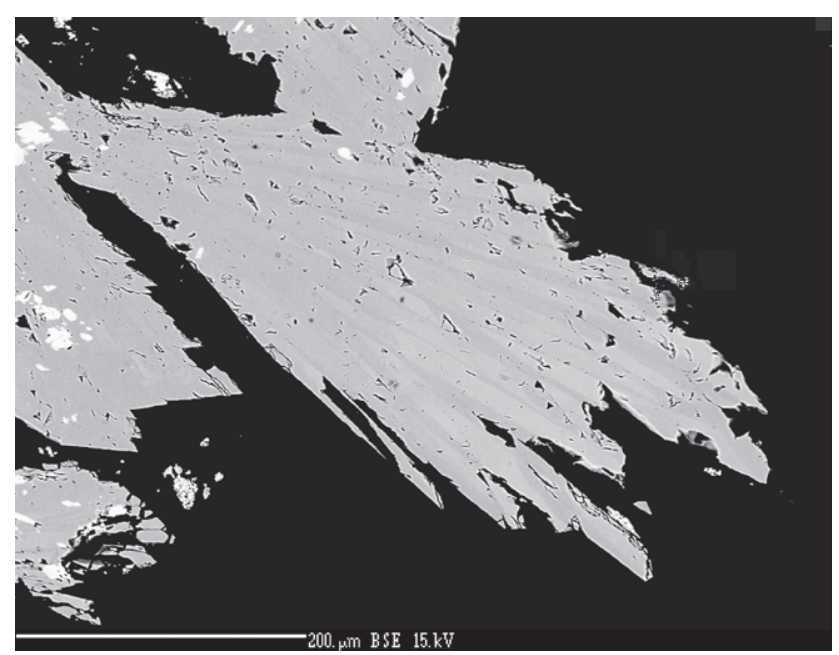

Figure 7. Chemical zonation of axinite-(Fe). Slightly brighter areas have a higher Fe:Mn ratio. Maglovec quarry, Vyšná Šebastová. BSE image

7. ábra. Kémiai zónásság axinit-(Fe)-kristályokban. A világosabb részeken kissé magasabb a Fe:Mn arány. Felsösebes, Maglovec-köfejtö. Visszaszórtelektron-kép

Bultfonteinite from calcium silicate xenoliths in the andesite quarry at Vechec (Vehéc)

The andesite quarry of Vechec is famous for its xenoliths (ĎuĎA et al. 1993). The most abundant types are those containing quartz-diopside and cordierite-sekaninaite, respectively, while the Ca-silicate xenoliths are much

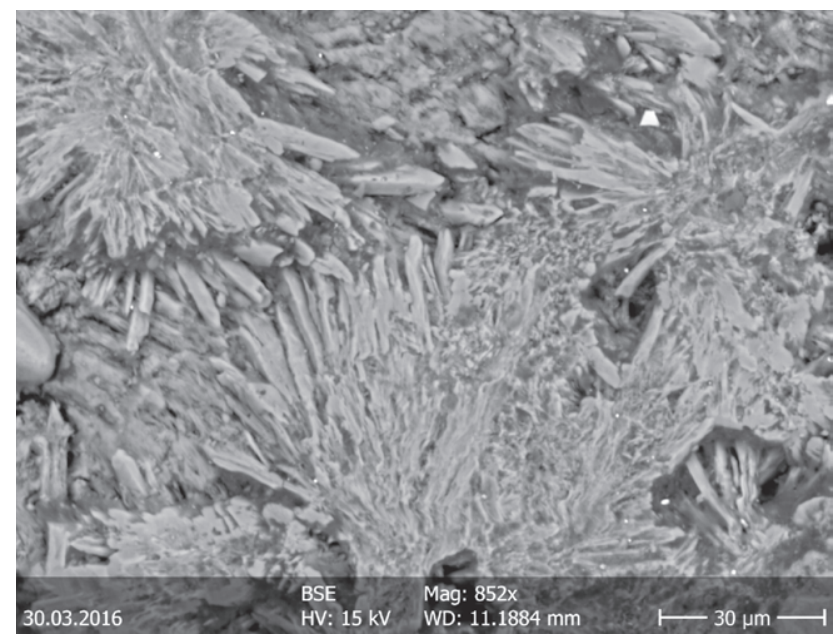

Figure 8. Radiating acicular aggregates of bultfonteinite. Andesite quarry of Vechec. BSE image

8. ábra. Tükböl álló bultfonteinit sugaras halmazai. Vehéc, andezitköfejtö. Visszaszórtelektron-kép rarer. The latter type is built up dominantly by aggregates of different Ca-silicates showing snow-white masses a few $\mathrm{cm}$ in size and having a pearly lustre. The Ca-silicates can be divided into primary phases and hydrated secondary phases which formed from the previous phases by hydration. The dominant phases are fibrous thaumasite and wollastonite, while the less abundant ones are isometric, subhedral katoite and bultfonteinite, which form needles and sprays up to $30 \mu \mathrm{m}$ in size (Figure 8). Based on the EDX data (27$29 \mathrm{wt} \% \mathrm{SiO}_{2}$ ), the hydrogarnet is the "hibschite" variety which represents an intermediate composition between katoite and grossular. The 3-4 wt \% $\mathrm{SO}_{3}$ content of the phase is worth mentioning. An $\mathrm{Mg}-\mathrm{Al}$ silicate (albeit not comprehensively identified) was also detected in the spe-

Table VI. Electron microprobe data of bultfonteinite from Vechec (in wt\%)

VI. táblázat. A vehéci bultfonteinit elektron-mikroszondás elemzési adatai tömegszázalékban

\begin{tabular}{|c|c|c|c|}
\hline $\mathrm{SiO}_{2}$ & 27.12 & 26.38 & 27.12 \\
\hline $\mathrm{TiO}_{2}$ & 0.05 & 0.08 & 0.04 \\
\hline $\mathrm{Al}_{2} \mathrm{O}_{3}$ & 2.32 & 1.49 & 0.86 \\
\hline $\mathrm{Cr}_{2} \mathrm{O}_{3}$ & 0.02 & 0.01 & 0.00 \\
\hline $\mathrm{MgO}$ & 0.08 & 0.04 & 0.03 \\
\hline $\mathrm{CaO}$ & 51.50 & 53.25 & 53.60 \\
\hline $\mathrm{MnO}$ & 0.05 & 0.01 & 0.00 \\
\hline $\mathrm{FeO}$ & 0.60 & 0.43 & 0.31 \\
\hline $\mathrm{NiO}$ & 0.00 & 0.02 & 0.00 \\
\hline $\mathrm{Na}_{2} \mathrm{O}$ & 0.05 & 0.00 & 0.00 \\
\hline $\mathrm{K}_{2} \mathrm{O}$ & 0.01 & 0.00 & 0.00 \\
\hline $\mathrm{F}$ & 6.25 & 8.36 & 7.92 \\
\hline $\mathrm{Cl}$ & 0.07 & 0.05 & 0.04 \\
\hline $\mathrm{H}_{2} \mathrm{O}^{*}$ & 14.20 & 12.96 & 13.27 \\
\hline $0=(F, C l)$ & -2.64 & -3.53 & -3.34 \\
\hline Total & 99.66 & 99.54 & 99.84 \\
\hline \multicolumn{4}{|c|}{$\begin{array}{l}\text { Ion numbers based on } 6 \text { anions } \\
\text { lonszámok } 6 \text { anionra }\end{array}$} \\
\hline $\mathrm{Si}$ & 0.95 & 0.93 & 0.96 \\
\hline $\mathrm{Ti}$ & 0.00 & 0.00 & 0.00 \\
\hline $\mathrm{Al}$ & 0.10 & 0.06 & 0.04 \\
\hline CI & 0.00 & 0.00 & 0.00 \\
\hline $\mathrm{Mg}$ & 0.00 & 0.00 & 0.00 \\
\hline $\mathrm{Ca}$ & 1.93 & 2.02 & 2.02 \\
\hline $\mathrm{Mn}$ & 0.00 & 0.00 & 0.00 \\
\hline $\mathrm{Fe}$ & 0.02 & 0.01 & 0.01 \\
\hline $\mathrm{Ni}$ & 0.00 & 0.00 & 0.00 \\
\hline $\mathrm{Na}$ & 0.00 & 0.00 & 0.00 \\
\hline K & 0.00 & 0.00 & 0.00 \\
\hline $\mathrm{F}$ & 0.69 & 0.94 & 0.88 \\
\hline $\mathrm{Cl}$ & 0.00 & 0.00 & 0.00 \\
\hline $\mathrm{OH}$ & 3.31 & 3.06 & 3.12 \\
\hline 0 & 2.00 & 2.00 & 2.00 \\
\hline
\end{tabular}

* Calculated from stoichiometry / A sztöchiometrikus összetételböl számolva: $\mathrm{OH}+\mathrm{F}+\mathrm{Cl}=4$ apfu. 
cimens. The youngest phases are vaterite and calcite which were identified in the cracks of the Casilicates by XRPD measurement (Table E4, see the electronic supplementary materials). Data for the chemical analyses of the bultfonteinite are very close to the theoretical values (Table VI). This is the first Carpathian occurrence of bultfonteinite.

\section{Botallackite from the Dobšiná (Dobsina) ore deposit}

A few years ago, light-blue and bluish-green secondary copper minerals were found as crusts in an abandoned site of the ore deposit of Dobšiná. As revealed by the XRPD and

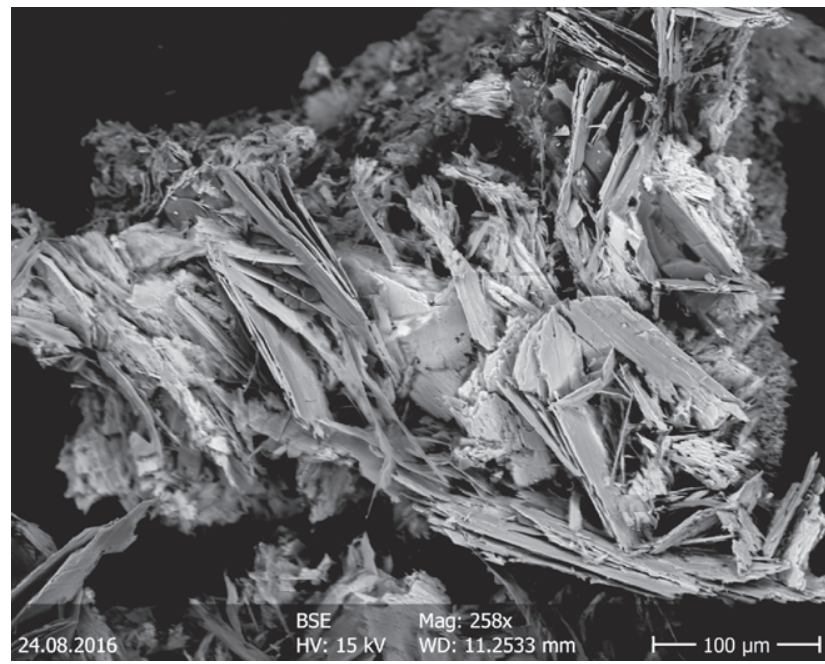

Figure 9. Lath-like botallackite crystals from Dobšiná. BSE image 9. ábra. Léces botallackitkristályok Dobsinából. Visszaszórtelektron-kép
SEM-EDX investigations, these crusts are built up by closely intergrown devilline, botallackite, gypsum and brochantite. Botallackite appears as 0.1-0.2 mm-long, greenishblue laths (Figure 9); devilline occurs as laths or needles of a similar size; and brochantite forms green or dark-green tabular crystals up to 1-3 mm, occurring as globular aggregates or crusts. The presence of botallackite, a rare copper chloride, was confirmed by XRPD (Table E5, see the electronic supplementary materials), while the presence of $\mathrm{Cu}$ and $\mathrm{Cl}$ in the mineral was detected by SEM-EDX. This is the first Carpathian occurrence of botallackite.

\section{Acknowledgements}

The authors are grateful to Michael NEUBAUER (Dobšiná) for the botallackite samples, Rudolf ĎuňA (Košice) for the axinite-(Fe) and bultfonteinite samples, Gábor KOLLER (Pilisborosjenő) for the pseudomalachite samples, and István HoRvÁTH (Miskolc) for the beaverite- $(\mathrm{Cu})$ samples. Both referees - Gheorghe ILINCA (University of Bucharest, Romania) and Uwe KoliTsCH (Naturhistorisches Museum Wien, Austria) - deserve much appreciation for their comments and suggestions. These helped to improve the manuscript considerably. The authors are also grateful to Gábor PAPP (Hungarian Natural History Museum, Budapest) who, during the process of editing, significantly raised the quality of the text. The research was carried out at the University of Miskolc, within the framework of the Thematic Excellence Program funded by the Ministry of Innovation and Technology of Hungary (Grant Contract reg. nr.: NKFIH-846-8/2019).

\section{References - Irodalom}

Crane, M. J., Sharpe, J. L. \& Williams, P. A. 2001: Formation of chrysocolla and secondary copper phosphates in the highly weathered supergene zones of some Australian deposits. - Records of the Australian Museum 53/1, 49-56. https://doi.org/10.3853/j.00671975.53.2001.1323

ĎUĎA, R. (ed.) 1981: Mineralógia severnej časti Slanských vrchov (Mineralogy of Eastern part of Slansky Mts.). - Mineralia Slovaca, Monografia 2, 98 p. (in Slovak)

ĎuĎA, R., SCHARMovÁ, M. \& ČERnÝ, P. 1993: Minerály xenolitov z Vechca (Slanské vrchy) (Minerals of xenoliths at Vechec, Slansky Mts.). - Zbornik Východoslovenská múzea v Košiciach. Prír. vedy 34, 17-29. (in Slovak)

FooRD, E. E. \& TAGGART, J. E. 1998: A re-examination of the turquoise group: the mineral aheylite, planerite (redefined), turquoise and coeruleolactite. - Mineralogical Magazine 62, 93-110. https://doi.org/10.1180/002646198547495

GuILLEMIN, C. 1956: Contribution a la minéralogie des arséniates, phosphates et vanadates de cuivre. I. - Bulletin de la Société française de Minéralogie et de Cristallographie 7, 7-95. https://doi.org/10.3406/bulmi.1956.5049

HATERT, F. \& BURKE, E. A. J. 2008: The IMA-CNMNC dominant-constituent rule revisited and extended. - Canadian Mineralogist 46, 717-728. https://doi.org/10.3749/canmin.46.3.717

Holland, T. J. B. \& RedFeRn, S. A. T. 1997: Unit cell refinement from powder diffraction data: the use of regression diagnostics. Mineralogical Magazine 61, 65-77. https://doi.org/10.1180/minmag.1997.061.404.07

KосH, S. 1966: Magyarország ásványai (Minerals of Hungary). - Akadémiai Kiadó, Budapest. 419 p. (in Hungarian)

Pouchou, J.-L. \& PichoiR, F. 1984: A new model for quantitative X-ray micro-analysis. - La Recherche Aerospatiale 3, 167-192.

SANERO, E. \& GotTARDI, G. 1968: Nomenclature and crystal-chemistry of axinites. - American Mineralogist 53, $1407-1411$.

Storci, S. D. 1983: Districtul metalogenetic Băița Bihorolui (Metallogenesis of Băița Bihor area). - Editura Academiei Republicii Socialiste Romania, Bucureşti. 189 p. (in Romanian) 
SzakÁLl, S., GATTER, I. \& Szendrei, G. 2005: A magyarországi ásványfajok (Mineral species of Hungary). - Kőország Kiadó, Budapest. 427 p. (in Hungarian)

SzakÁll, S., Kristály, F. \& Zajzon, N. 2012: Minerals of turquoise group from Sândominic, Gurghiu Mts., Romania and from Parádfürdő, Mátra Mts., Hungary. - Acta Mineralogica-Petrographica, Abstract series 7, 133.

Manuscript recieved: 20/06/2019

Plate I - I. tábla
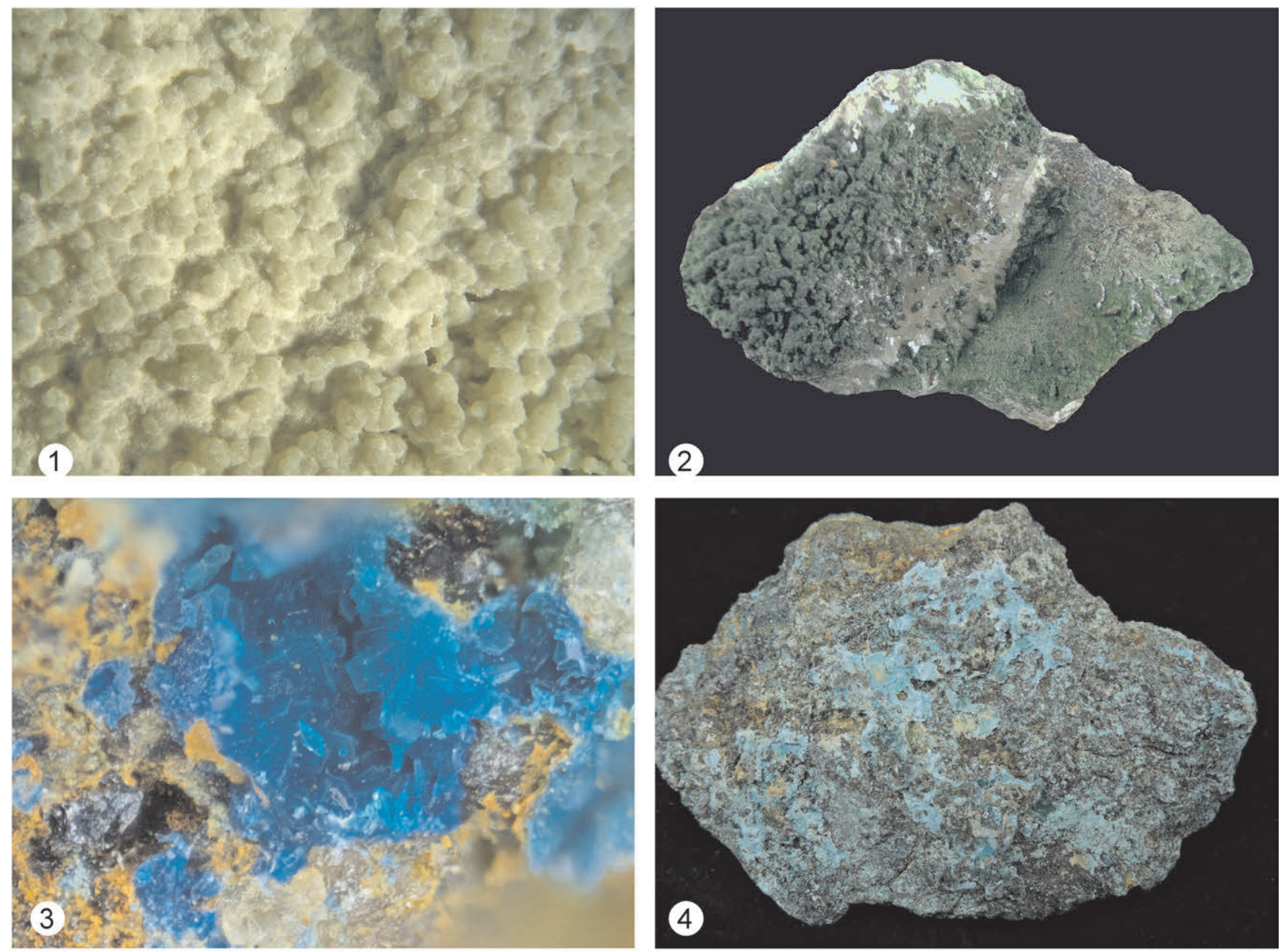

1. Globular aggregates of planerite-faustite-aheylite-turquoise solid solution, Parádfürdő. Width of picture: $2 \mathrm{~cm}$. J. NYúL (Recsk) collection.

2. Green crusts of conichalcite-duftite solid solution on white calcite. Băița Bihor. Specimen size $11 \mathrm{~cm}$. Herman Ottó Museum collection (Photo: Á. BERENTÉs).

3. Pale blue crystals of pseudomalachite, pseudomorphs after azurite. Ocna de Fier. Width of the picture: $2.7 \mathrm{~mm}$. Herman Ottó Museum collection (Photo: L. TótH)

4. Aggregates of greenish blue botallackite and pale blue devilline. Dobšiná. Specimen size $5.5 \mathrm{~cm}$. Herman Ottó Museum collection.

1. Planerit-faustit-aheylit-türkiz elegykristályok gömbös halmazai. Parádfürdö. Képszélesség: 2 cm. NYúL J. (Recsk) gyüjteménye.

2. Konikalkit-duftit elegykristályok zöld bekérgezései fehér kalciton. Rézbánya. A példány mérete $11 \mathrm{~cm}$. Herman Ottó Múzeum gyüjteménye (Berentés Á.felvétele).

3. Pszeudomalachit világoskék kristályai, álalakok azurit után. Vaskö. Képszélesség: 2,7 mm. Herman Ottó Múzeum gyüjteménye (Tóth L. felvétele).

4. Botallackit (zöldeskék) és devillin (világoskék) halmazai. Dobsina. A példány mérete $5,5 \mathrm{~cm}$. Herman Ottó Múzeum gyüjteménye. 